\title{
Література:
}

1. Кодекс адміністративного судочинства України: Закон України від 06.07.2005 p. № 2747-IV / Верховна Рада України. URL: https://zakon.rada.gov.ua/laws/show/2747-15\#Text.

2. Радишевська О.Р. Адміністративне та цивільне право в умовах євроінтеграції: на стику доктрин. Правова держава. 2020. № 37. С. 80-89.

3. Тимчишин Т.М. Адміністративно-правовий договір як акт правового застосування. Загальна характеристика. Науковий вісник Львівського державного університету внутрішніх справ. 2018. № 2. C. 199-207.

4. Шкварок Л.В. Функції договору в приватному праві. Філософські та методологічні проблеми права. 2011. № 1. С. 124-134.

5. Зварич Р.В., Гривнак Б.Л. Регулятивна функція права у системі функцій права. Науково-інформаційний вісник Івано-Франківського університету права імені Короля Данила Галицького. Серія: Право. 2017. № 4(16). С. 20-28.

6. Чорнобай О.Л. Комунікативна функція права: інформаційноінформаційний вимір. Науковий вісник Львівського державного університету внутрішніх справ. 2013. № 1. С. 496-507.

DOI https://doi.org/10.30525/978-9934-588-92-1-63

\section{ПУБЛІЧНЕ АДМІНІСТРУВАННЯ ЯК ЗАСІБ ЗАХИСТУ ПРАВ, СВОБОД ТА ІНТЕРЕСІВ ГРОМАДЯН}

\author{
Косміна I. A. \\ викладач вищої категорії відділення «Правознавство» \\ Харківського державного автомобільно-дорожнього коледжу \\ Гончаренко Н. М. \\ викладач вищої категорії відділення «Правознавство» \\ Харківського державного автомобільно-дорожнього коледжу \\ м. Харків, Україна
}

Сучасний стан української державі є дуже складним. Він перебуває на такому етапі розвитку, що змушує переосмислювати і змістовно розвивати цілу низку усталених понять, що максимально впливає на 
зміст державного управління, яке повинно бути адекватним ситуації, яка склалася, iї негативним і позитивним складовим.

Організація публічної влади ніколи не залишається незмінною; вона постійно перебуває в розвитку. У цьому аспекті державно-правові системи, як справедливо зазначається в сучасній теоретичній літературі, завжди були i залишаються «перехідними», тобто такими, що перебувають на переході від одного стану держави і права до іншого. Саме в такому, перехідному стані й перебуває нині, за оцінками фахівців, Україна.

Це пов'язано з тим, що відбувається стратегічне усвідомлення та реалізація нових обріїв розвитку держави. Проте прийняття Конституції України дало можливість провести низку суттєвих політико-правових реформ, спрямованих на формування більш ефективної, сучасної системи публічної влади, наближеної до населення, відповідальної перед людиною й орієнтованої на забезпечення іiі прав і свобод. Однак успіх реформ значною мірою залежить від якості відповідної науковометодичної бази. Кожний крок на шляху до модернізації держави i місцевого самоврядування, перш ніж бути здійсненим, повинен отримати належне наукове обгрунтування, організаційну й матеріально-фінансову підтримку.

До основних ознак держави належить: територія, яка визнана світовою спільнотою; люди, які пов'язані з державою громадянством (підданством); публічна влада; норми права; податки; державний примус, який може застосовуватися публічною владою для захисту від порушень норм права чи несплати податків; та зовнішні атрибути (прапор, гімн, герб). Ці ознаки є універсальними, властивими будь-якій державі.

Ознаки, які характеризують публічну владу:

1) об’єднує народ, (населення країни) за територіальною ознакою, створює територіальну організацію підвладних об'єктів, політичну асоціацію інтегрованих відносин та інститутів;

2) здійснюється спеціальним апаратом, відокремленим від суспільства, для керівництва ним із застосуванням різних владних методів (заохочення, переконання і примусу);

3) володіє суверенітетом, який означає незалежність реалізації публічної влади від бажань чи небажань об'єктів влади;

4) верховенство, обов'язковість іiі рішень для іншої влади;

5) публічність, тобто всезагальність і безособовість, що є виразом усезагальної волі ; 
6) нормативне регулювання суспільних відносин, що виявлено в можливості публічної влади видавати загальнообов'язкові правила поведінки.

Публічна влада - це здатність публічних суб'єктів впливати на суспільні відносини між людьми 3 приводу організації їхньої сумісної діяльності на основі реалізації публічного інтересу.

Публічна влада ширша за змістом, ніж державна влада, оскільки публічні суб'єкти - це органи державно влади i місцевого самоврядування та інші невладні суб'єкти делегованих владних повноважень під час здійснення виконавчих функцій. Тим самим будьяка державна влада $\epsilon$ публічною, але не всяка публічна влада $\epsilon$ державною.

Під публічним адмініструванням розуміють всю систему адміністративних інститутів із ієрархією влади, за допомогою якої відповідальність за виконання державних рішень спускається зверху донизу, відповідно, публічне адміністрування - це скоординовані групові дії з питань державних справ, які:

- пов'язані із трьома гілками влади (законодавчою, виконавчою і судовою);

- мають важливе значення у формуванні державної політики; $\epsilon$ частиною політичного процесу;

- значно відрізняються від адміністрування у приватному секторі;

- пов'язані із багаточисельними приватними групами та індивідами, які працюють у різних компаніях та громадах [2].

Публічне управління - це організуючий i регулюючий вплив держави, що здійснюється на основі волевиявлення громади (колективу людей) на суспільну життєдіяльність людей з метою ії впорядкування, збереження чи перетворення, опираючись на владну силу, яку обмежує дієвий суспільний контроль та реалізується суб'єктами, визначеними громадою, для задоволення потреб і досягнення цілей громади як об'єкту управління.

Специфіка публічного управління полягає у тому, що спирається на державну владу, підкріплюється і забезпечується нею; поширюється на все суспільство і за його межі у сфері проведення державної міжнародної політики; діє системно, поєднуючи функціонування таких структур, як механізм держави, державний апарат, державну службу i публічні прояви суспільства.

Залежність управляючого впливу від стану системи і зовнішнього середовища, передбачає, що будь-яка система публічного адміністрування функціонує в конкретному соціальному середовищі, 
тобто в межах конкретного суспільства і властивих йому економічних відносин, соціальної структури, культурного середовища, соціальнопсихологічної атмосфери.

Засади публічного управління адекватні основним положенням змішаної формації та солідаристичної цивілізації та базуються на цінностях громадянського суспільства та демократизації суспільних процесів.

Велике значення мають поняття системності та інституціональності публічного управління, тобто застосування положень системного аналізу та синтезу і сучасних теорій інституціоналізму в теорії та практиці публічного управління. Вони розширюють іiі концептуальну основу - ідеї. Вони складають основоположні засади теорії публічного управління.

1. Публічне управління спрямоване на забезпечення загального блага, суспільного цінностей, цілей, інтересів і потреб.

2. Публічне управління виступає як цілісність управлінського процесу від ідентифікації інтересу та/чи потреби особи до оцінки результату їх вирішення: тобто управлінських процесів: ідентифікації інтересу та/чи проблеми особи, формування інтересів та/чи потреб громади (територіальної, професійної тощо) та їх представлення у публічній політиці, перетворення публічної політики демократичним шляхом у державну політику, реалізація державної політики механізмом держави та оцінювання суб'єктами публічної сфери результатів впровадження державної політики.

3. Публічне управління має системний i інституціональний характер, де системоутворюючим фактором виступають цінності, цілі та потреби колективу, громади та суспільства, відношення між суб'єктами публічної сфери мають характер взаємодії та взаємосприяння та регулюються суспільно визнаними інститутами (правилами, нормами, традиціями тощо) та інституціями (органами публічного управління).

4. Публічне управління - засіб консолідації громади та суспільства навколо бачення майбутнього громади та суспільства, національної ідеї тощо, а також засіб забезпечення солідарності громад і суспільства та держави у визначенні цінностей і цілей розвитку суспільства і шляхів їх досягнення, збереження тощо.

5. Публічне управління надає сутності управлінської діяльності характер спрямованості на цінності, цілі та потреби громади, відкритості, солідарності, раціоналізму та безпосередньої причетності особи до вирішення проблем громади; забезпечує результативність i ефективність управлінського процесу за рахунок доцільного та 
своєчасного використання ресурсів на основі сучасних методів управління.

6. Суб'єкти публічної сфери є органічними складовими єдиного публічного управлінського механізму та орієнтовані на цінності (у тому числі й соціальна справедливість), цілі, потреби громади та ії окремих членів як споживачів послуг адміністративних структур публічного управління.

7. Результати діяльності публічної сфери, іiі складових i матеріальних придатків механізму публічного управління $є$ основою оцінювання результативності та ефективності функціонування системи публічного управління та їі суб'єктів.

8. Управлінська ланка публічного управління має бути організована у публічну службу відповідальну як перед громадянами, яким служить, так і перед політичним керівництвом за реалізацію публічної політики.

9. Публічне управління спонукає до емансипації творчої активності особи, синергетики активності громади та суспільства.

У сучасних умовах України, коли громадянське суспільство, публічна сфера, багато складових політичної системи ще не повною мірою сформувалися, саме публічна політика має стати єдиним виразником загальних інтересів усіх верств суспільства. Через формування публічної політики та іiі впровадженням інституціональним середовищем (інституціями та інститутами) публічного управління має формуватися солідарність між суспільством країни та державою як системою відносин, спрямованих на реалізацію цінностей суспільства та досягнення цілей публічної політики. Вкрай важливим для солідаристичної цивілізації та змішаної формації суспільства $\epsilon$ усвідомлення жителями країни необхідності солідарності суспільства та держави. При цьому сильна публічна політика можлива лише на базі інтенсивного розвитку соціально орієнтованої ринкової економіки, громадянського суспільства, громадянської культури та солідарності, що має велике значення в приватномужитті членів суспільства і при політичному волевиявленні громадян. Для демократичного впливу визначальним є метод дискурсивного формування суспільної думки та дискурсивного волевиявлення

Звісно, трансформаційні процеси можуть відбуватися 3 певними недоліками, одним із яких на сучасному етапі державного будівництва в Україні є те, що всупереч п. 12 ст. 92 Конституції [1], згідно з яким організація і діяльність органів виконавчої влади, основи державної служби визначаються виключно законами, відповідне законодавство досі не прийняте. Але, саме тому Верховна Рада України якнайшвидше має врегулювати законодавчі прогалини щодо організації державного 260 
управління i місцевого самоврядування, прискорити розгляд законопроектів про Кабінет Міністрів України, про центральні органи виконавчої влади, про адміністративно-територіальний устрій, нової редакції Закону «Про місцеве самоврядування в Україні» (а можливо, й Муніципального кодексу), щоб потім логічно продовжити конституційне регулювання відповідно до потреб поступального розвитку країни, адже задоволення потреб і досягнення цілей громади фактично означає функціонування та розвиток колективу людей, а відповідно і європейський розвиток всієї держави.

1. Конституція України

\title{
Література:
}

2. Адміністративне право України. Повний курс: підручник / Галунько В. Діхтієвський П., Кузьменко О., Стеценко С. та ін. Херсон: ОЛДІ-ПЛЮС, 2018.446с. ISBN 978-966-289-184-3

3. Мальковская И. А. Трансформация государства и эволюция публичного администрирования в условиях глобализации (актуализация европейского опыта для России) / И. А. Мальковская // Вестн. Рос. ун-та дружбы народов. - 2006. - № 8. - С. 27-43. - (Серия: Политология).

DOI https://doi.org/10.30525/978-9934-588-92-1-64

\section{ПРАВОВА ХАРАКТЕРИСТИКА ВUG ВОUNТY (БАГ БАУНТІ) ЯК ПЕРСПЕКТИВНОГО МЕХАНІЗМУ ЗАБЕЗПЕЧЕННЯ ІНФОРМАЦІЙНОЇ БЕЗПЕКИ}

\author{
Мельянков В. С. \\ студент другого року навчання магістратури \\ Інституту права
}

Київського національного університету імені Тараса Шевченка м. Київ, Україна

У наш час вже навряд можна здивувати когось, зауваживши, що інформація - один із найцінніших ресурсів сьогодення. Бажання володіти цінними ресурсами, у свою чергу, є природнім прагненням людини, яке може бути задоволено як правомірним, так $\mathrm{i}$ неправомірним шляхом. За таких умов, питання захисту інформації $\epsilon$ 